\title{
CONTINENTAL WEATHERING AND CLIMATIC CHANGES INFERRED FROM CLAY MINERALOGY AND PAIRED CARBON ISOTOPES ACROSS THE EARLY TO MIDDLE TOARCIAN IN THE PARIS BASIN
}

Michaël Hermoso $^{\mathrm{a}}$ and Pierre Pellenard ${ }^{\mathrm{b}}$

${ }^{a}$ University of Oxford - Department of Earth Sciences. South Parks Road, Oxford OX1 3AN, United Kingdom.

${ }^{b}$ UMR CNRS 6282 Biogéosciences, Université de Bourgogne, 6 Boulevard Gabriel, 21000 Dijon, France.

Corresponding author. E-mail: Michael.Hermoso@earth.ox.ac.uk. Tel: +44 (0) 1865272003.

\section{HIGHLIGHTS}

- Relatively cold climate during the earliest Toarcian, before the negative CIE

- Cooling, yet to be fully established, immediately prior to black shale deposition

- Enhanced kaolinite abundance in sediments during the negative CIE

- Near-instantaneous decrease in the continental weathering after the CIE

- After the CIE, sustained long-term greenhouse conditions up to the bifrons Zone

\begin{abstract}
Lower Toarcian strata (Lower Jurassic) have been extensively studied with a view to understanding the oceanographic, climatic and biological processes that drove the Earth's system into an Oceanic Anoxic Event (OAE). For this time period, the evolution of the European marine seaways is now relatively well constrained owing to multiple geochemical studies, but investigations regarding climatic trends in the continental realm remain sparse. In the present study, we test the clay mineralogy as a continental climate-sensitive proxy in the well-documented Sancerre core (southern Paris Basin). We compare variations in the kaolinite content with $p \mathrm{CO}_{2}$ fluctuations (derived from paired carbon isotopes; $\Delta^{13} \mathrm{C}=\delta^{13} \mathrm{C}_{\text {carb }}$ $-\delta^{13} \mathrm{C}_{\text {org }}$ ), taking advantage of the detailed chemostratigraphic, palaeoenvironmental and sequence stratigraphy frameworks established for this core material. The results indicate a substantial decrease in kaolinite abundance at the end of the Pliensbachian, which is compatible with a long-term diminution in continental weathering and an inferred temperature decrease. The early Toarcian, prior to the carbon cycle perturbation and deposition of black shale facies, remained relatively cold with minima in both the proportion of kaolinite and reconstructed $p \mathrm{CO}_{2}$. The mineralogical and geochemical responses across the prominent negative carbon isotope excursion (CIE) itself are not univocal. The first of four steps that compose the negative limb of the CIE at Sancerre is associated with decreased kaolinite and $p \mathrm{CO}_{2}$, and increased carbonate oxygen isotope ratios. Taken together, these trends are compatible with a transient cooling phase immediately preceding the onset of black shale deposition. Conversely, the subsequent steps are marked by substantial enrichment in
\end{abstract}


kaolinite that matches increased osmium isotope ratios measured in Yorkshire, providing compelling evidence for rapid increases in continental weathering and riverine runoff forced by intensification of greenhouse conditions during the CIE. Relaxation in the intensity of continental weathering, as suggested by resumed low kaolinite abundance is seen immediately after the cessation of $\mathrm{CO}_{2}$ input (after the fourth step of the CIE). The interval spanning the upper portion of the early Toarcian and the middle Toarcian records a subsequent long-term increase in the proportion of kaolinite synchronous with significant clay enrichment of the sediment. Continued greenhouse conditions, even after the recovery from the carbon isotope perturbation and "regional" black shale deposition, are likely related to sustained $\mathrm{CO}_{2}$ emission by Karoo-Ferrar volcanism through the considered interval.

Keywords: Jurassic; Toarcian OAE; Clay mineralogy; Paired carbon isotopes; Paris Basin.

\section{Introduction}

A number of periods marked by transient elevation in atmospheric $\mathrm{CO}_{2}$ level occurred during the Mesozoic and are referred to as "hyperthermal" events (Jenkyns, 2003). These short-lived events represent sudden disruption of the carbon cycle, intensification of greenhouse conditions, and elevation in Sea Surface Temperatures (SSTs). The most severe of these events culminated into protracted episodes of oxygen depletion and widespread deposition of black shales, a phenomenon referred as to Oceanic Anoxic Events (OAEs) (see Jenkyns, 2010 for a review). The main sources forwarded to account for excess $\mathrm{CO}_{2}$ in the atmosphere and accompanying climatic and biotic changes are thought to derive from volcanic and/or methane hydrate reservoirs (Jenkyns, 2003, 2010; references therein). Among these Mesozoic hyperthermal events, that of the early Toarcian (183Ma) is marked by a series of perturbations in the Earth system, including a second-order biological crisis (sensu Raup and Sepkoski, 1984). The Pliensbachian and the Toarcian Stages have experienced high background $p \mathrm{CO}_{2}$ likely due to the activity of the Karoo-Ferrar Large Igneous Province (Ducan et al., 1997; Jourdan et al., 2008; Moulin et al., 2011; Pálfy and Smith, 2000). Substantial organic carbon enrichment is observed in lower Toarcian sediments in Europe, as represented by the Schistes carton Formation in France, the Jet Rock Formation in England, or the Posidonienschiefer Formation in Germany with Total Organic Carbon (TOC) concentrations yielding $15 \%$ (Fig. 1; Baudin et al., 1990).

Additionally, the most prominent negative carbon isotope excursion (CIE) of the Mesozoic recorded in the early Toarcian pinpoints possible injection of isotopically light $\mathrm{CO}_{2}$ into the atmosphere (Hesselbo et al., 2000, 2007; Kemp et al., 2005; Hermoso et al., 2009a; Hesselbo and Pienkowski, 2011). This sharp isotopic event $(-7 \% 0)$ is near coincident with the onset of black shale deposition in the European epicontinental seas at the top of the Dactylioceras tenuicostatum Zone suggesting a causal link (Hermoso et al., 2009a; Hesselbo et al., 2000; Röhl et al., 2001; Suan et al., 2013). Not only did the carbon cycle experience elemental and isotopic disruption, but a generalised perturbation of the chemistry of seawater, recognised in $\mathrm{I}, \mathrm{Li}, \mathrm{Mg}, \mathrm{Mn}, \mathrm{Mo}, \mathrm{N}, \mathrm{Na}, \mathrm{O}, \mathrm{Os}, \mathrm{Re}, \mathrm{S}, \mathrm{Sr}$ elements and/or isotopes occurred with the deposition of black shales (Bailey et al., 2003; Cohen et al., 2004; Gill et al., 2011; Hermoso et al., 2009b; Jenkyns et al., 2001; Jones and Jenkyns, 2001; Lu et al., 2010; 
McArthur et al., 2000; 2008; Newton et al., 2010; Pearce et al., 2008; Van de Schootbrugge et al., 2005). These "spikes" testify indeed for pronounced climatic and oceanographic changes. Attempts to reconstruct Toarcian SSTs predominantly derived from changes in the oxygen isotopic composition of carbonate (Bailey et al., 2003; Dera et al., 2009a; Dera et al., 2011; Gómez and Goy, 2011; Hermoso et al., 2009a; Rosales et al., 2004). Interpreting $\delta^{18} \mathrm{O}$ at face values may, however, give biased SST estimates due to concomitant changes in the oxygen isotope composition of seawater owing to fluctuations fresh water ( ${ }^{16} \mathrm{O}$ input) supply in epicontinental seaways (Dera et al., 2009a; Saelen et al., 1996). A possible decrease in seawater $\delta^{18} \mathrm{O}$ may be inferred in the epicontinental seaways on the basis of the osmium isotope profile that indicates acceleration of the riverine supply at the time of the negative CIE (Cohen et al., 2004). Another possible source of ${ }^{16} \mathrm{O}$ that can mimic a warming when incorporated into carbonate, may derive from Arctic waters owing to the opening of the Viking Strait during this period (Bjerrum et al., 2001; Dera et al., 2009a; Dera and Donnadieu, 2012).

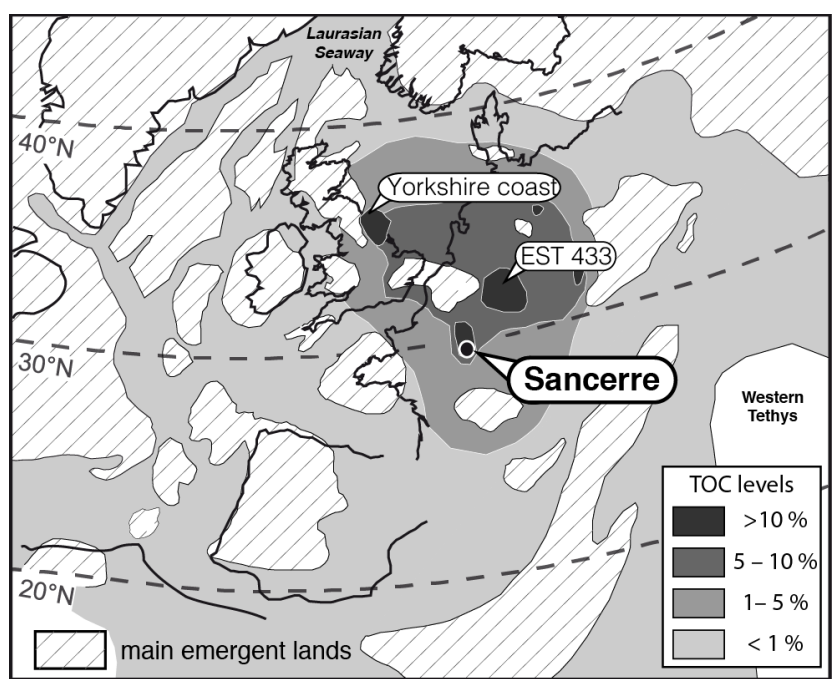

Fig. 1: Palaeogeographic map of the Early Jurassic archipelago (now positioned in NW Europe), and the geographic distribution of organic-rich rocks. Greyscale shades indicate the content range of Total Organic Carbon (TOC); key is embedded bottom right. Emergent lands delineating the basins are hatched. The map indicates the location of the Sancerre and ANDRA EST 433 boreholes in the Paris Basin and the Yorkshire sections in the Cleveland Basin. Source: Bassoulet et al. (1993); Baudin et al. (1990); Van de Schootbrugge et al. (2005); Hermoso et al. (2009b).

Palaeo- $p \mathrm{CO}_{2}$ estimates indicate an increase of $1200 \mathrm{ppm}$ using the reduction in the stomatal index on leafs recovered from a section in Denmark (McElwain et al., 2005). The authors tentatively translated this figure into atmospheric temperatures, and suggested a $6.5^{\circ} \mathrm{C}$ greenhouse warming. Despite the aforementioned reservation about the use of $\delta^{18} \mathrm{O}$ for SST reconstruction, it is noteworthy that this temperature rise would match the $-1.5 \%$ shift recorded in $\delta^{18} \mathrm{O}$ of the well-preserved coccolith-bearing Sancerre core (Hermoso et al., $2009 \mathrm{a}$ ) or in $\mathrm{Mg} / \mathrm{Ca}$ ratios of belemnites recovered from Yorkshire and German sections (Bailey et al., 2003).

To date, previous works on the Sancerre core (southern Paris Basin; Fig. 1) have generated long-term $\delta^{13} \mathrm{C}$ and $\delta^{18} \mathrm{O}$ records, and the evolution in some trace metals for the 
interval spanning the Pleuroceras spinatum - Harpoceras serpentinum Zones (Hermoso et al., $2009 a ; 2009 b)$. Subsequently, high-resolution estimates of $p \mathrm{CO}_{2}$ and seawater saturation state with respect to calcium carbonate were produced for a short interval corresponding to the onset of the CIE and of black shale deposition (Hermoso et al., 2012). This latter study revealed a "precursor event" consisting of a volcanically-driven $p \mathrm{CO}_{2}$ rise culminating in a "carbonate crash" across the first step of the negative CIE. Recently, the evolution of the redox state of the water column was attempted for this same site and compared to a sea level change framework for an extended stratigraphic interval up to the Hildoceras bifrons Zone in the middle Toarcian (Hermoso et al., 2013). These incremental works make the Sancerre core one of the most studied lower Toarcian section. A recently-published ammonite and nannofossil work now allows better biostratigraphic constraints on this core material (Boulila et al., 2014). Importantly, the nannofossil biozonation now clearly establishes that the carbon isotope excursion is expressed at the base of the NJ6 Zone, as found in other sections (Mailliot et al., 2006), and hence, confirming the synchronicity of this prominent geochemical event at the scale of NW European basins.

In the present contribution, we document the evolution in the assemblage of clay minerals for this reference core section. Clay mineralogy has been extensively used as a proxy for constraining Jurassic climate and quantifying the intensity of continental weathering (Brański, 2010; 2012; Deconinck and Bernouilli; 1991; Deconinck et al., 2003; Dera et al., 2009b; Hesselbo et al., 2009; Pellenard and Deconinck, 2006; Raucsik and Varga, 2008). Particularly, the relative proportion of kaolinite, as a marker of continental runoff, has the potential to constrain palaeoclimatic conditions and the hydrographic regime that prevailed in the continent through pedogenesis and physico-chemical weathering. Our purpose here is to compare these new data to the well-constrained pacing of events previously established for Sancerre, in parallel, of new and extended record of paired carbon isotopes $\left(\Delta^{13} \mathrm{C}=\delta^{13} \mathrm{C}_{\text {carb }}\right.$ $\delta^{13} \mathrm{C}_{\text {org }}$ ) used to infer $p \mathrm{CO}_{2}$ for the Toarcian (Hermoso et al. 2012; Hollander et al., 1991; Röhl et al., 2001).

\section{Material and methods}

The studied interval represents an extended stratigraphic interval compared to the recent studies on the Sancerre core (Hermoso et al., 2009a; 2009b; 2012), and corresponds to that recently studied by Hermoso et al. (2013) spanning the late Pliensbachian (spinatum Zone) to middle Toarcian (bifrons Zone) sub-Stages. This incremental study was performed using clay and isotope data with a resolution step of $50 \mathrm{~cm}$ along the $52 \mathrm{~m}$ of the core.

\subsection{Clay mineralogy}

About 60 samples were investigated for clay mineralogy using X-Ray Diffraction (XRD). Clay mineral assemblages were identified on oriented slide mounts using a Brucker D4 Endeavour diffractometer with $\mathrm{CuK} \alpha$ radiations, LynxEye detector and Ni filter under 40 $\mathrm{kV}$ voltage and $25 \mathrm{~mA}$ intensity at University of Bourgogne. The goniometer scanned from $2.5^{\circ}$ to $28.5^{\circ}$ for each run. X-ray diffractograms were performed from decarbonated $(0.2 \mathrm{M}$ $\mathrm{HCl})$ finely powdered rock and clay sized particles $(<2 \mu \mathrm{m})$ after settling and centrifugation. 
In order to distinguish between the main clay phases, three preparations of the same sample were analysed after $i$ ) Air-drying, ii) Ethylene-glycol solvation, and iii) heating at $490{ }^{\circ} \mathrm{C}$, following international procedure (Moore and Reynolds, 1997). Clay minerals were identified using the position of the main reflections on the three XRD runs. About 5 samples distributed along the section were check under the SEM using back-scattered electrons on whole rock specimens to check their detrital or authigenic origin (Chamley, 1989). In particular, we checked for presence of authigenic vermicular kaolinite.

Quantification of each clay mineral assemblage was classically determined from glycolated run diffractograms. Measurements of the area of (001) peaks were achieved using the MacDiff 4.2.5 software (Petschick, 2000). Clay minerals investigated included: R1 type illite-smectite mixed-layer mineral (near $11.5 \AA$ ), illite $(10 \AA)$ ), chlorite $(14.2 \AA)$, and kaolinite $(7.18 \AA)$. In order to discriminate and determine accurate content of kaolinite and chlorite, the (004) chlorite / (002) kaolinite ratio corresponding to the $3.52 \AA / 3.58 \AA$ ratio was used to calculate the relative proportion of these minerals, as the $7.18 \AA$ peak contains both (002) chlorite and (001) kaolinite peaks. Percentage of chlorite was then measured as the mean of the (001) chlorite (at $14.2 \AA$ ) and the (002) chlorite (at 7.1 $\AA$ ) peak areas. Beyond evaluation of clay minerals relative proportions, the objective here is to identify fluctuations in their relative abundances throughout the core. The evolution in the relative ratios retrieved from peak areas is therefore considered for the results and discussions.

\subsection{Stable isotope from the organic matter}

Forty-five samples were measured for the carbon isotope composition of bulk organic matter $\left(\delta^{13} \mathrm{C}_{\mathrm{org}}\right)$. Samples were decarbonated $(10 \% \mathrm{HCl})$ and rinsed three times with deionised water. Residues were weighed in tin capsules and introduced into a Carlo Erba EA coupled to Europa Geo 20-20 mass spectrometer at the Research Laboratory for Archaeology and the History of Art of the University of Oxford. The isotopic reference used for the measurements is an internal nylon standard $\left(\delta^{13} \mathrm{C}_{\text {org }}=-26.16 \% \pm 0.21 \mathrm{~V}\right.$-PDB $)$. The measurements were standardised against the Nylon 66 international standard. Paired carbon isotopic ratios $\left(\Delta^{13} \mathrm{C}\right)$ were calculated as the difference between $\delta^{13} \mathrm{C}_{\text {carb }}$ and $\delta^{13} \mathrm{C}_{\text {org. }}$. Carbon isotope ratios of carbonate $\left(\delta^{13} \mathrm{C}_{\text {carb }}\right.$ ) are taken from various sources (Hermoso et al., 2009a; 2012; 2013). The use of $\Delta^{13} \mathrm{C}$ as a $p \mathrm{CO}_{2}$ proxy relies on the decreasing ${ }^{13} \mathrm{C} /{ }^{12} \mathrm{C}$ kinetic fractionation in the organic matter by phytoplankton (Arthur et al., 1985; Freeman and Hayes, 1992), whereas that associated with biomineralisation (carbonate) is insensitive to ambient dissolved organic carbon levels. Because the physiology of Jurassic primary and calcifying producers (the coccolithophores) is unknown, we only used $\Delta^{13} \mathrm{C}$ as trends, and refrained from translating the figures into $p \mathrm{CO}_{2}$ estimates.

\section{Results}

\subsection{Clay assemblage and kaolinite abundance}

The total clay content in the Sancerre deposits fluctuates significantly over the late Pliensbachian - middle Toarcian interval with minimum values of $30-40 \%$ during the 
serpentinum Zone in the Toarcian. The upper Pliensbachian and middle Toarcian sediments are the most argillaceous with $\sim 70 \%$ of clay minerals (Fig. 2). The abundance of clay parallels the concentration of aluminium measured by X-ray fluorescence by Hermoso et al. (2013).

The main clay minerals identified on diffractograms performed on Sancerre sediments consist of chlorite, illite, R1 illite-smectite mixed-layer minerals (IS R1), and kaolinite (Fig. 2). The chlorite content does not vary significantly across the studied interval, with mean abundance of $\sim 10 \%$. Illite represents an important phase of the clay assemblage, with average values of around 20 - $25 \%$. IS R1 and kaolinite both show more substantial variations of their abundances.

The ratio between kaolinite and IS R1 + illite, described as the $K / I+I S$ ratio thereinafter, shows two long-term changes during the terminal Pliensbachian and the top of the serpentinum Zone, and a very short-term fluctuation at the onset of the black shale deposition.

During the late Pliensbachian, the $K / I+I S$ curve shows a rapid decline that starts from maximum ratio $(\sim 1)$ to minimum ratio $(\sim 0.25)$ characterising the lowermost Toarcian sediments (Fig. 3). A slight increase in the $K / I+I S$ ratio can be observed during the earliest Toarcian but these low ratios remain stable up to $335 \mathrm{~m}$, disregarding a transient excursion between 348.20 and $347.40 \mathrm{~m}$.

The first step of the negative CIE $(348.85 \mathrm{~m})$, which occurred in advance to black shale deposition at Sancerre is seen with increased $\delta^{18} \mathrm{O}$ values and minimum abundance proportion of kaolinite $(K / I+I S$ of $\sim 0.15)$ (Figs. 3, 4). Although the minimum in the $K / I+$ $I S$ curve is defined here by one single sample, replicated analysis confirmed this low ratio.

With the subsequent steps of the CIE and the onset of black shales ("Sc 1" sensu Hermoso et al., 2013; Fig. 4), the kaolinite proportion slightly but gradually increases. The $K / I+I S$ decreases immediately after the fourth step of the CIE at $347.40 \mathrm{~m}$. It is noteworthy that this is the only short-term fluctuation of the $K / I+I S$ ratio observed for the whole studied interval. The ratios remain stable and very low through "Sc 2" (342 to $335 \mathrm{~m}$ ).

After $335 \mathrm{~m}$, the kaolinite proportion, and the proportion of all clays in sediment, rapidly increases (Figs. 2,3). This interval corresponds to the third black shale interval of the section ("Sc 3"). This increase persists up to the bifrons Zone. The top of the interval, from 317 m upwards exhibits diminished $K / I+I S$ ratios. 


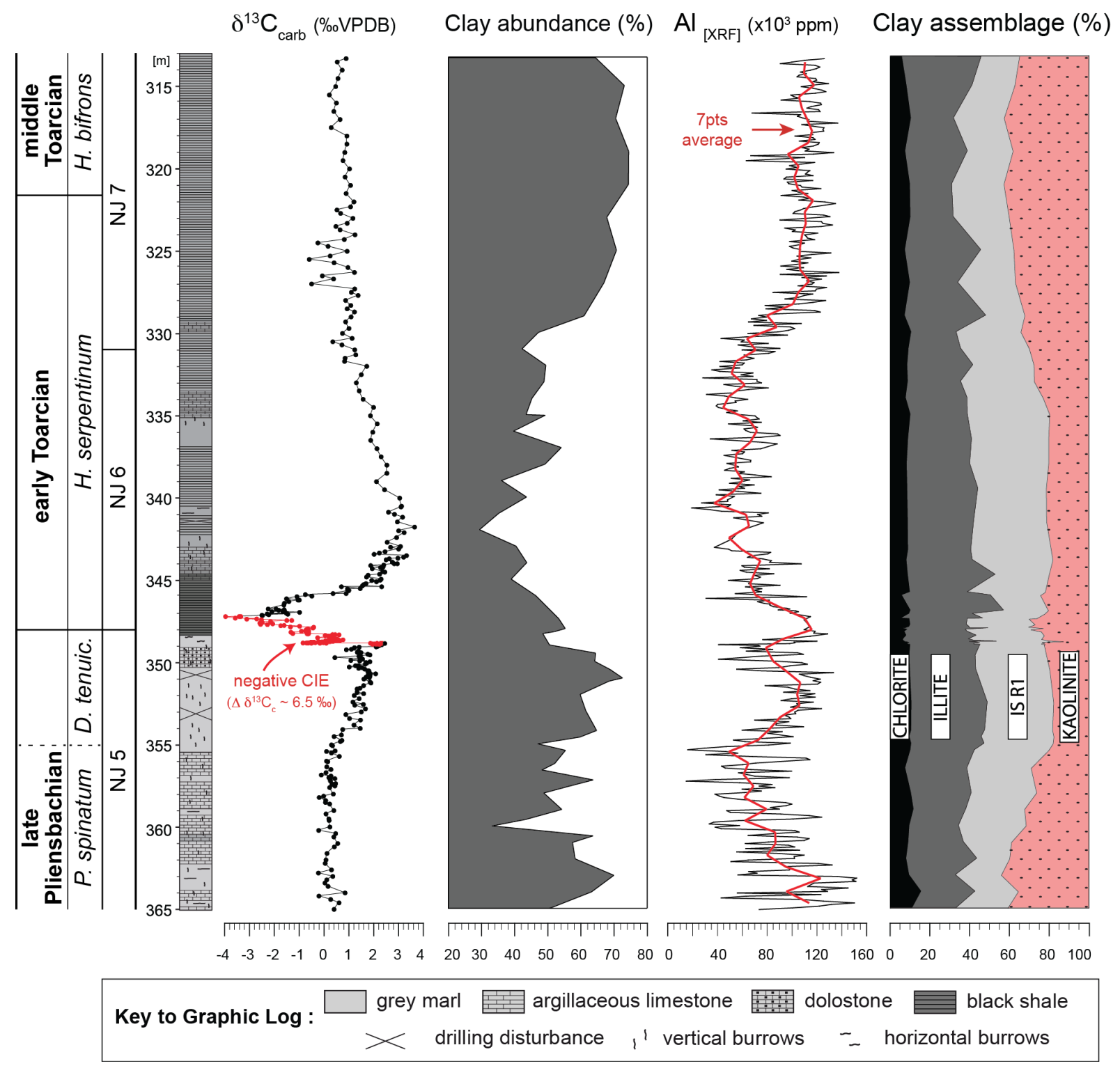

Fig. 2: Carbon isotope stratigraphy, clay content and clay mineralogy for the late Pliensbachian to middle Toarcian for the Sancerre core (southern Paris Basin). Clay assemblages mainly consist of chlorite, illite, R1 illite-smectite and kaolinite. The curve indicating \%wt of clay parallels that of the aluminium content measured by X-Ray Fluorescence. Data source: $\delta^{13} C_{\text {carb }}$ and log: Hermoso et al. (2012; 2013); Clay content determined by XRD and aluminium concentrations ([AI]) determined by XRF: Hermoso et al. (2013); Clay mineral assemblages: present study. The biostratigraphic framework is taken from Boulila et al. (2014). 


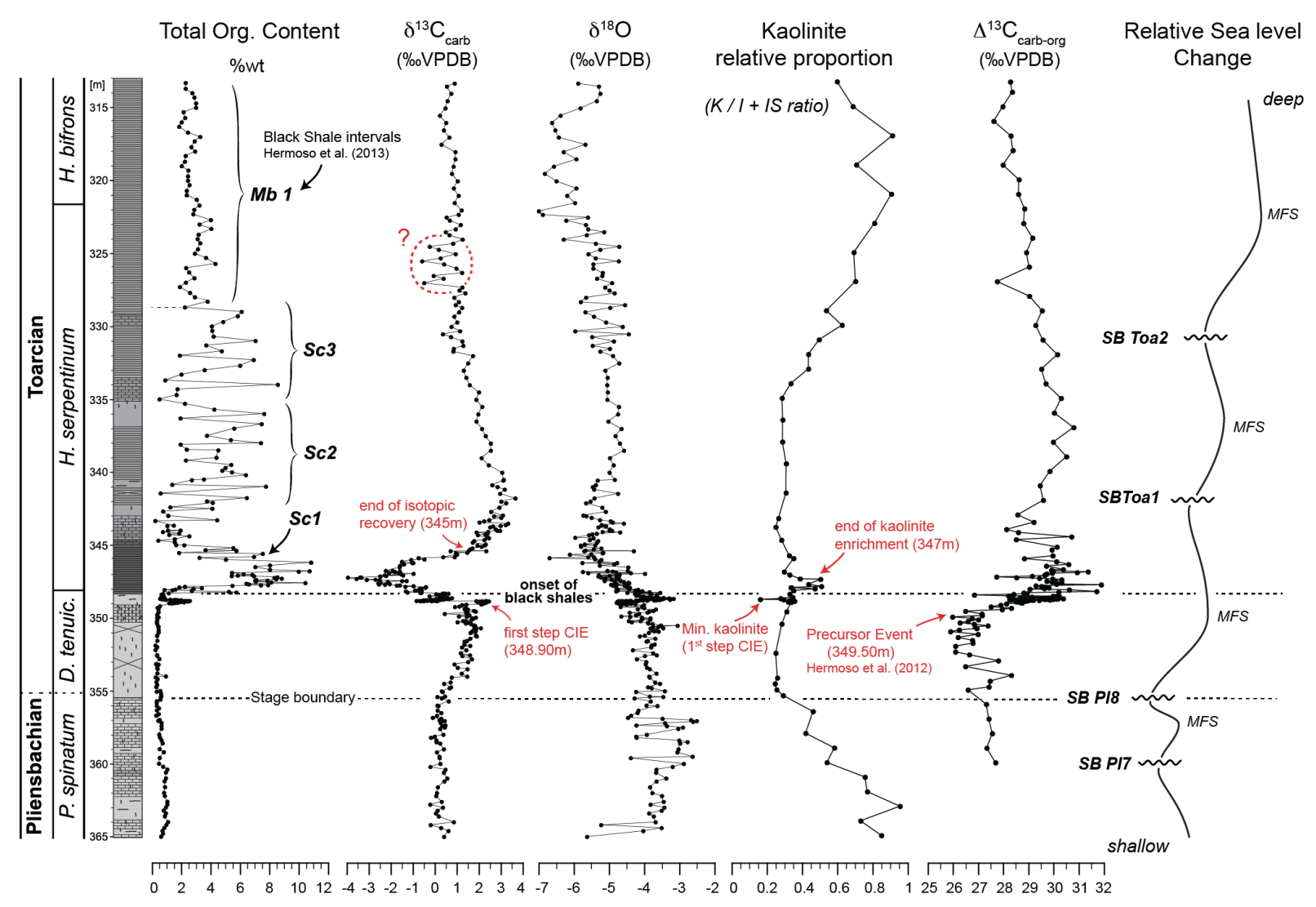

Fig. 3: Black shale occurrences, chemostratigraphy $\left(\delta^{13} C_{c a r b}, \delta^{18} O, \Delta^{13} C\right)$, kaolinite relative content expressed as a proportion to other clay minerals $(K / I+I S R 1)$, and inferred sea level change during the late Pliensbachian to middle Toarcian in the Sancerre core. Two long-term changes in kaolinite abundance are observed: $A$ decrease during the late Pliensbachian, and an increase from $335 \mathrm{~m}$ (top of serpentinum Zone). The kaolinite contents during the early Toarcian (tenuicostatum Zone) are minimum, except in the interval recording the negative carbon isotope excursion $(349-347 \mathrm{~m})$. Data source: TOC, $\delta^{13} C_{\text {carb, }} \delta^{18} O$ : Hermoso et al. (2012; 2013); $\Delta^{13} C$ 360-344m: Hermoso et al. (2012) and stratigraphically above: present study; K/I + IS R1: present study; Relative sea level curve: Hermoso et al. (2013).

\subsection{Evolution in $\Delta^{13} \mathrm{C}$ and inferred $\mathrm{pCO}_{2}$ across the Toarcian}

The supplementary and new data of the present study that complement that of Hermoso et al. (2012) show diminished $\Delta^{13} \mathrm{C}$ values between 346.50 and $344.00 \mathrm{~m}$ (recovery interval) leading to values of $\sim 28 \%$. Palaeo- $p \mathrm{CO}_{2}$ estimates are yet higher compared to those recorded before the CIE. A subsequent increase is registered between 343 and $337 \mathrm{~m}$ and is accompanied by a $1 \%$ increase in $\delta^{18} \mathrm{O}$. For the whole interval subsequent to the CIE, there is a striking parallel between $\Delta^{13} \mathrm{C}$ and $\delta^{18} \mathrm{O}$. The long-term decrease in $\Delta^{13} \mathrm{C}$ at the top of the serpentinum Zone and base of the bifrons Zone is also seen with decreased $\delta^{18} \mathrm{O}$ and increased kaolinite ratios. 


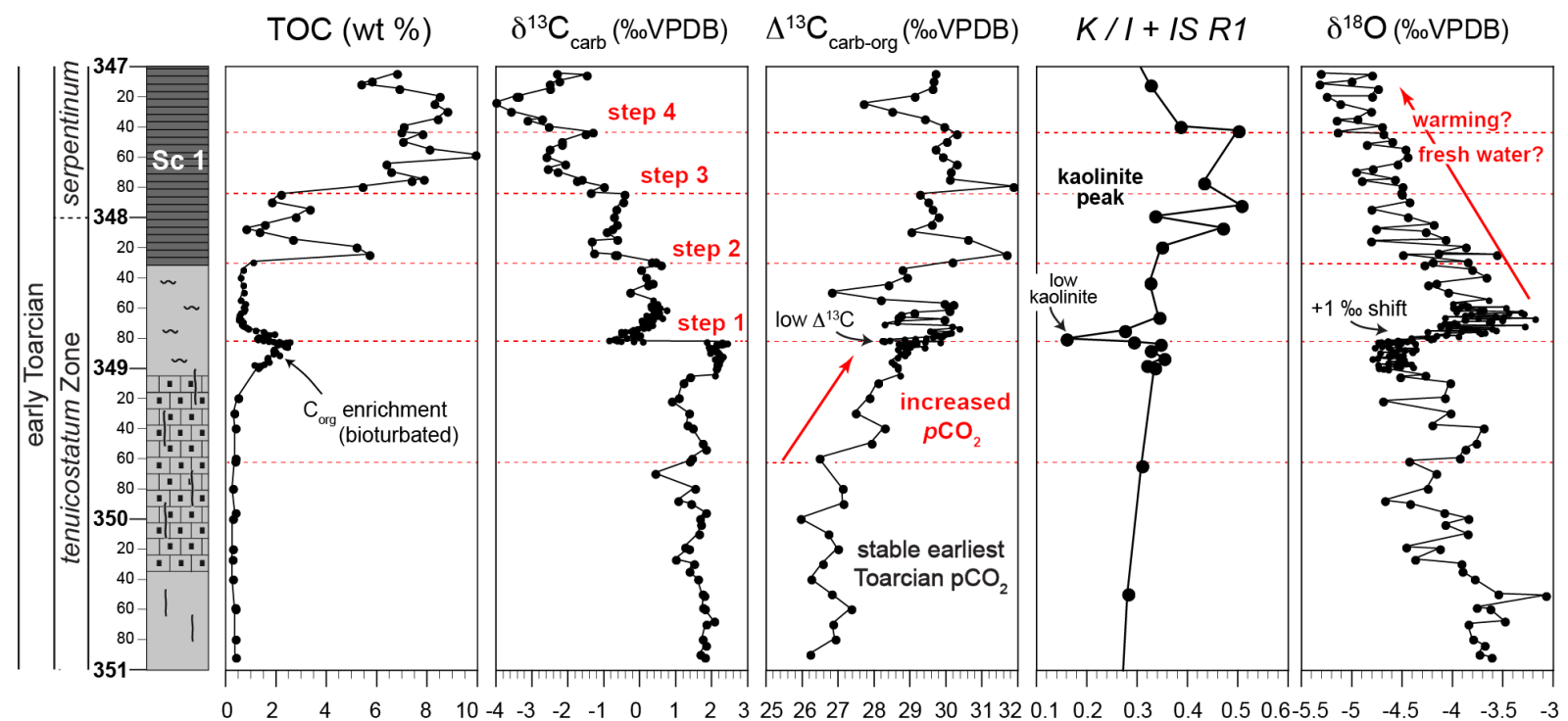

Fig. 4: Close-up on the $351-347$ metre interval showing $\% T O C, \delta^{13} C_{c a r b}, \Delta^{13} C$, kaolinite abundance expressed as the $K / I+I S R 1$ ratio, and $\delta^{18} O$ across the negative CIE. Horizon dash lines represents the main geochemical events; substantial increase in $\Delta^{13} C$ at 349.60 m ("precursor event" with probable volcanic origin; Hermoso et al., 2012), and the fourth successive negative steps that compose the CIE. The first step of the CIE is observed with diminution in kaolinite proportion and $\Delta^{13} C$, and increased $\delta^{18} O$. Taken at face values, they may indicate transient cooling (see discussion in text). Concomitant to the second to fourth step of the negative CIE, substantial kaolinite enrichment is registered and is compatible to intensification of greenhouse conditions. Data source: refer to the caption of Fig. 3.

\section{Discussion}

\subsection{Diagenesis and depositional control of kaolinite abundance}

An examination of randomly selected samples from the upper Pliensbachian and the lower and middle Toarcian by backscattered scanning electron microscopy indicates that clays are present mainly as detrital minerals. No features of alteration of feldspar into kaolinite or easily recognisable authigenic kaolinite with a booklet, or vermicular shape were observed. The argillaceous nature and low porosity of the lower and middle Toarcian sediments may have prevented any major fluid circulation that could favour precipitation of in situ kaolinite aggregates. The same property of these clayey strata may explain limited precipitation of late diagenetic carbonate (Hermoso et al., 2009a). Palaeotemperature reconstruction studies from the centre and east of the Paris Basin indicate a maximum thermal burial around of $90^{\circ} \mathrm{C}$ for Toarcian sediments (Blaise et al., 2013; Disnar, 1996; Ménétrier et al., 2005). These temperatures have to be regarded as conservative estimates as they were obtained for the centre of the basin. On the Paris Basin borders, the $\sim 2 \mathrm{~km}$ burial depth and the very low thermal maturity of the organic matter suggest unsubstantial to moderate illitisation and chloritisation (Debrabant et al., 1992; Delavenna et al., 1989). If these burial temperatures may introduce discrete diagenesis as illitisation of smectite-rich clay minerals (Lanson et al., 2009), they cannot affect kaolinite, whose dissolution and transformation into 
illite occurs at higher temperatures (Bentablo et al., 2003; Chamley, 1989; Lanson et al., 2002; Mantovani et al., 2010). The absence of direct control of the lithology on the kaolinite content is supplementary evidence that diagenesis and fluids have not significantly affected the primary signature of clay minerals. Detrital origin of mixed-layer is more difficult to establish as partial illitisation of smectite-rich minerals are compatible with the considered temperatures. Therefore we have used the $K / I+I S$ ratio that mirrors the proportion of kaolinite that we assume detrital versus the proportion of illite and mixed-layers that may derive partly from burial diagenesis. This ratio is used as a primary palaeoclimatic proxy assuming $i$ ) that kaolinite formed in subtropical contemporaneous soils or are reworked from ancient soils during intense continental runoff (Dera et al., 2009b; Pellenard and Deconinck, 2006; Thiry, 2000) and ii) that illite and IS R1/smectite-rich mineral suggest more arid conditions (Chamley, 1989; Pellenard and Deconinck, 2006).

\subsection{Long-term climatic trend during the end of Pliensbachian}

The record of a clear diminution in the relative proportion of kaolinite during this interval can be explained by a substantial decrease in the intensity of continental weathering. This diminution in kaolinite abundance was previously recognised by Dera et al., (2009b) for most peritethyan areas during the davoei-tenuicostatum biozones. This interval is thought to correspond to relatively cold climate and evidence for ice sheet emplacement exist at the Pliensbachian - Toarcian boundary (Chandler et al., 1992). Diminished $\Delta{ }^{13} \mathrm{C}$ and increased $\delta^{18} \mathrm{O}$ values during late Pliensbachian are compatible with lowered $p \mathrm{CO}_{2}$, although it has to be acknowledged that this evidence comes from few isotopic data in this interval. Nevertheless, other isotopic records confirm a cooling at the end of the Pliensbachian (Bailey et al., 2003; Dera et al., 2011; Dera and Donnadieu, 2012; Suan et al., 2010). The ${ }^{87} \mathrm{Sr} /{ }^{86} \mathrm{Sr}$ profile also suggests progressive decrease in the continental weathering leading to minimum values $(\sim 0.7071)$ in the long-term curve by Jones and Jenkyns (2001).

This prominent decrease in kaolinite abundance has also to be discussed in terms of sea level change. Based on the well-establish long-term sequence stratigraphy for European basins (de Graciansky et al., 1998; Hallam, 2001) and inferred relative sea level curve proposed for the Jurassic of the Paris Basin (Guillocheau et al., 2000; Hermoso et al., 2013; Lorenz and Gély, 1994), the late Pliensbachian experienced an episode of sea level fall (Fig. 3). As kaolinite is preferably stored on proximal borders and dependent on the platform morphology (Chamley, 1989; Gibbs, 1977; Godet et al., 2008; Pellenard and Deconinck, 2006), a drop in kaolinite content and consecutively in the $K / I+I S$ ratio could be driven by a transgressive pattern that would take result in a by-pass of kaolinite, or by the emplacement of a platform on which relatively coarse clay mineral such as kaolinite will be deposited. These scenarios are however incompatible with the late Pliensbachian regression. Hence, a palaeoclimatic control on the kaolinite abundance has to be favoured to explain relatively high kaolinite contents in the late Pliensbachian. The late Pliensbachian regression is not compatible with the observed decrease of kaolinite and therefore, we retain a palaeoclimatic control on kaolinite abundance trend in this interval. High kaolinite contents, however, are likely due to the low sea level that favours kaolinite deposition sedimentation. 
In the earliest Toarcian, the tenuicostatum Zone interval exhibits relatively stable $\delta^{18} \mathrm{O}$ and $\Delta^{13} \mathrm{C}$ ratios, and lowest values of kaolinite content in advance to the major climatic perturbations (CIE and black shales), are compatible with a relatively "cool" early Toarcian climate (Brański, 2012; Dera et al., 2009a; 2009b).

\subsection{Short-term fluctuations associated with the negative CIE}

\subsubsection{The "precursor event" and first step of the CIE}

Immediately before the onset of black shale deposition and the concomitant kaolinite enrichment, a minimum in kaolinite ( $13 \%$ compared to $22 \%$ in average for the tenuicostatum - serpentinum Zones interval with minimum values of kaolinite) is coincident with the first step of the CIE (Fig. 4). This low value is only supported by one mineralogical data point (even if replicated). However, this exact stratigraphic level corresponds to a sharp increased oxygen isotope ratio showing a $+1 \%$ shift potentially suggesting short-term cooling phase. As each step of the CIE is thought to represent injection of carbon into the Atmosphere Ocean system (Hesselbo et al., 2000, 2007; Hesselbo and Pienkowski, 2011; Kemp et al., 2005), there is a paradox that needs to be reconciled for the first step. Indeed the injection of greenhouse gas, either in form of $\mathrm{CH}_{4}$ or $\mathrm{CO}_{2}$ cannot induce cooling. Mineralogical examination of the carbonate particles through the first step showed a shift from coccolithdominated to protodolomite-dominated carbonate possibly recording sea floor temperatures (Hermoso et al., 2012). Hence, there is an uncertainty as to whether this $\delta^{18} \mathrm{O}$ shift represents cooling. This interval also corresponds to an episode of seawater acidification and reduced pelagic particles export to the seafloor, at least demonstrated for Sancerre (Hermoso et al., 2012), and in other Mediterranean sections at a longer stratigraphic scale (Trecalli et al., 2012). On the other hand, a burst in volcanism and an accompanying $\mathrm{SO}_{2}$ emission leading to a cooling of the atmosphere and acidification of ocean may be invoked (Prueher and Rea 2001; Robock 2000). Independent temperature estimates, as through generation of reliable $\mathrm{TEX}_{86}$ or $\Delta_{47}$-derived SSTs may be envisaged to test this hypothesis. Nevertheless, if a cooling phase preceding the onset of the black shale event at Sancerre proves to be true, this would represent a striking similarity between the T-OAE and the OAE 2 at the Cenomanian Turonian transition (Voigt et al., 2004).

\subsubsection{Second step of the CIE and onset of black shale deposition}

At $\sim 348.25 \mathrm{~m}$, the onset of black shale deposition ("Sc 1" sensu Hermoso et al., 2013; Fig. 3) coincides with the second step of the negative excursion in $\delta^{13} \mathrm{C}$. This level is also marked by a short-lived augmentation in the proportion of kaolinite as seen by an increase in the $K / I+I S$ ratio (Fig. 4). This kaolinite peak only persists throughout a portion of the black shale interval "Sc 1". It has to be acknowledged that this transient kaolinite enrichment is only half amplitude compared to long-term changes observed in the spinatum and bifrons Zones. As this level corresponds to a prominent and sharp change in the lithofacies separating the underlying grey mudstone and the finely laminated black shales at $348.25 \mathrm{~m}$, a lithological effect could be suspected assuming subsequent modification of sedimentation and/or by local diagenetic microenvironement associated with high content of organic matter. 
However as kaolinite content decreases within the black shale interval, this hypothesis can be ruled out.

This critical level occurred within a pronounced elevation in the $\Delta^{13} \mathrm{C}$, possibly indicating increased ambient $\mathrm{CO}_{2}$ levels. Hermoso et al. (2012) suggested a tipping point in the causal relationship between substantial $\mathrm{CO}_{2}$ levels and triggering of anoxia. With the development of the first black shale interval, reinforcement in the increase of atmospheric $\mathrm{CO}_{2}$ levels, enhanced kaolinite supply and deposition to the basin provide compelling evidence for intensification of greenhouse conditions concomitant from the second step of the negative CIE. This climatic feature is only observed in the first black shale interval "Sc 1" (Fig. 3).

It is also still unresolved whether the $1.5 \%$ decrease in $\delta^{18} \mathrm{O}$ values with the emplacement of black shales is attributable to a warming stage and/or to increased fresh $\left({ }^{16} \mathrm{O}\right.$ rich) water to the basin. The osmium-isotope curve generated from the Yorkshire coast by Cohen et al. (2004) may be suggestive for the latter driver for the $\delta^{18} \mathrm{O}$ shift. An additional argument indicating sudden acceleration in the continental weathering at this level comes from a pronounced increase in the slope of ${ }^{87} \mathrm{Sr} /{ }^{86} \mathrm{Sr}$ curve (McArthur et al., 2000). The decrease of kaolinite abundance to low background values is recorded within "Sc 1". Conversely $\delta^{18} \mathrm{O}$ remained negatively shifted during this interval, favouring a temperature control on oxygen isotopes. The same remark applies for osmium isotopes, but not for strontium due to much longer residence time.

To date, only a few sections have been documented for their clay content at highresolution, but there seems to be a hint of kaolinite coeval with the deposition of the early Toarcian black shales (see review by Dera et al., 2009b). Further high-resolution mineralogical studies are required to document the intensity of the continental throughout the T-OAE, particularly for geochemically well-constrained sections. In a recent study on a core material drilled in the NE of the Paris Basin (ANDRA EST 433; Fig. 1), Lézin et al. (2013) have performed a multiproxy palaeoenvironmental study including clay mineralogy for the early Toarcian. They document similar clay assemblage with respect to the Sancerre core material, but the negative CIE is not accompanied by kaolinite enrichment, as it is the case at Sancerre. In the NE of the Paris Basin, the generalised hiatus around the late Pliensbachian early Toarcian is particularly developed (Hanzo and Espitalié, 1994), and the Schistes carton Formation corresponds to a very condensed interval compared to Sancerre, or to Jet Rock and Bituminous Shales Formations cropping out at the Yorkshire coast (Fig. 1). In the vicinity of the core ANDRA EST 433, a previously-documented Toarcian section, the ANDRA HTM 102 core, showed that the negative CIE is even hardly recognised in NE France (van Breugel et al., 2006). Taking into account the brevity of the kaolinite enrichment episode recognised in this study, it is possible that this event was not preserved in the NE Paris Basin.

\subsubsection{Recovery of the CIE}

Kaolinite ratios returned to pre-CIE values immediately after the fourth step of the CIE ( 347 m; Figs. 3, 4). This relationship between the CIE and our climate-sensitive proxy, would indicate that the end of excess ${ }^{12} \mathrm{C}$ was near-instantaneous, probably due to carbon absorption by the oceanic system. The very rapid diminution in kaolinite supply to the basin 
after the cessation of $\mathrm{CH}_{4} / \mathrm{CO}_{2}$ emission illustrates that removal of excess $\mathrm{CO}_{2}$ from the atmosphere was extremely rapid and that clay mineralogy signature has the ability to record high-frequency variations in the continental weathering, as observed for high-resolution studies (Moiroud et al., 2012). The peak in osmium isotopes also terminates with the most negative $\delta^{13} \mathrm{C}_{\text {org }}$ values in Yorkshire (Cohen et al., 2004). By contrast, if we take the recovery in $\Delta^{13} \mathrm{C}$ as an indicator for the dissolved inorganic carbon levels, namely the $\mathrm{CO}_{2}$ of the marine reservoir, it appears that resumed background carbon levels are recorded later, at about $345 \mathrm{~m}$ in the core (Fig. 3). This delinking between the atmospheric and oceanic carbon reservoirs may be explained by the very rapid dynamics of the carbon cycle in the atmosphere relative to the latency of the marine reservoir, which owes to the buffering capacity of surface waters.

\subsection{Post-CIE changes during the late early Toarcian and middle Toarcian}

The aftermath of the carbon cycle perturbation during the serpentinum Zone was characterised by persistent greenhouse conditions (Dera et al., 2011). Oxygen isotope ratios, $\Delta^{13} \mathrm{C}$, and palynological data confirm a warm climate after the negative CIE, as also recorded at Sancerre. However, there is an ambiguity in our data that show increased $\delta^{18} \mathrm{O}$ concomitant with increased $\Delta^{13} \mathrm{C}$ in the $345-337 \mathrm{~m}$ interval. The kaolinite proportion was stable and minimum. Hence, we cannot infer subsequent intensification of greenhouse after the CIE. Between 345 and $337 \mathrm{~m}$, two major events are revealed: A second black shale interval (termed "Sc 2" in Hermoso et al., 2013; Fig. 3), and an episode of relative sea level rise. The most straightforward explanation may rely on combined effects of increased sea level and increased $\mathrm{pCO}_{2}$. The latter factor would explain deposition of black shale facies ("Sc 2") forced by elevation in atmospheric $\mathrm{CO}_{2}$ levels. The lack of a CIE in this interval rules out a second destabilisation of methane hydrates. A volcanically-induced scenario appears to be plausible at this stratigraphic level, as a persistent Karoo-Ferrar activity has been demonstrated for the late tenuicostatum Zone (Ducan et al., 1997; Pálfy and Smith, 2000; Jourdan et al., 2008; Moulin et al., 2011). With increased sea level, increased distance of Sancerre from the coast, the effect in fresh water supply and kaolinite input may have been lowered.

The onset of the third black shale interval ("Sc 3" at $\sim 335 \mathrm{~m}$ ) is recorded with a pronounced and long-term rise in the kaolinite abundance that terminates in the bifrons Zone. Such enrichment in kaolinite is observed in adjacent sections in Europe at the top of the serpentinum and in the bifrons Zones (Dera et al., 2009b). In parallel, both $\Delta^{13} \mathrm{C}$ and $\delta^{18} \mathrm{O}$ declined through this interval. The sea level rise during this interval that enhanced clay deposition, should favour IS R1 sedimentation, as these clay particles are smaller in comparison to kaolinite. Therefore, higher relative abundance of kaolinite (Fig. 3) is interpreted as more humid and warm conditions for this period, as it is observed at the scale of the eastern Tethyan realm (Dera et al., 2009b). The middle Toarcian has received much less attention than the early Toarcian because it is not associated with any sudden isotopic excursion or with biological extinctions. Existing data, however, seem to indicate warm climate during the bifrons Zone (Bailey et al. 2003; Dera et al., 2011; Gómez and Arias, 
2010; Gómez and Goy, 2011; Léonide et al., 2012). Radiometric dates of the Karoo-Ferrar LIP, particularly from basalts exposed in the Lesotho region indicate continued volcanic emission during the middle Toarcian (Jourdan et al., 2008; Moulin et al., 2011).

The very argillaceous nature of the Marnes à Bifrons Formation corresponds to the expression of a second and third-order maximum flooding surfaces marking a high sea level state (Guillocheau et al., 2000; Hermoso et al., 2013). Increased kaolinite abundance in the clay fraction in this lithostratigraphic unit may be related to sustained high continental weathering. Bottom water anoxia is indicated by the presence of sediment lamination, probably in a context of Regional OAE (sensu McArthur et al., 2008) or post-T-OAE "Mb 1" (Hermoso et al., 2013). The significance of a $-2.5 \%$ negative excursion in the $\delta^{13} \mathrm{C}$ at the base of "Mb 1" (327.80 to $324 \mathrm{~m}$ ) has still to be established, and sought in equivalent levels of other sections.

It may appears somehow contradictory that the putative volcanic event coeval and responsible for "Sc 2" was not accompanied by a negative CIE, whereas this is observed for "Mb 1" (Fig. 3). Refining radiochronological ages for the Lesotho rocks may enable correlating pulses in Karoo-Ferrar activity and the onsets of these black shale intervals. Furthermore, if such a volcanic trigger hypothesis has to be retained, precise petrographic work has to be undertaken to determine the nature of the volcanism. Jourdan et al. (2007) documented silicic magmatism from $\sim 178 \mathrm{Ma}$, that may coincide with the bifrons Zone in the marine record. As noted by Suan et al. (2008), we know that the volcanic context and the provenance of the lava may have consequences on $\delta^{13} \mathrm{C}$ of volcanic $\mathrm{CO}_{2}$ (Deines, 2002). Hence, it may appear plausible that the negative CIE at the base of "Mb 1" (328 m) may have been caused by release of ${ }^{12} \mathrm{C}$-rich $\left(\delta^{13} \mathrm{C} \sim-25 \%\right) \mathrm{CO}_{2}$ as a response of a change in the source of the magma, or by possible subduction of organic-rich rocks from Lower Jurassic sedimentary formations. Further constrains on the dynamics of the Karoo-Ferrar activity, together with a modelling effort of the carbon cycle in the future may represent a valuable work on this topic.

\section{Conclusions}

The perturbation of the carbon cycle ascribed to the negative CIE appears to be an epiphenomenon at the scale of the late Pliensbachian to middle Toarcian interval. Our study highlights the short-lived nature of the CIE-associated perturbation in the continent resulting in enhanced continental weathering, and confirms the near instantaneous response of the climate-sensitive proxies as clays, especially the kaolinite content, or previously-reported osmium isotopes in Yorkshire (Cohen et al., 2004). On a longer timescale, this study corroborates a cooling and arid phase at the end of the Pliensbachian, a relatively cold and dry early Toarcian (disregarding the interval comprising the CIE) and subsequent warm and humid climate associated with post-CIE black shales in the second half part of the serpentinum Zone. A methane hydrate release event within successive volcanic episodes from the Karoo-Ferrar activity was likely responsible for cumulative carbon inputs into the atmosphere, subsequently increased the intensity of the continental weathering and black shale deposition for the late Pliensbachian to middle Toarcian interval. Our data bear, however, an ambiguity as to whether a possible transient cooling occurred with the first step 
of the negative CIE that may be resolved if considering "cooling gases" release from volcanic activity such as $\mathrm{SO}_{2}$. For the whole late Pliensbachian to middle Toarcian interval, and in particular across the negative CIE, further work is required to be able to interpret $\delta^{18} \mathrm{O}$ values in terms of temperature decoupling a possible a fresh water supply effect.

\section{Acknowledgements}

We thank Ludovic Bruneau (Bourgogne University) for XRD analysis, and Pete Ditchfield (RLAHA Oxford) for running the mass spectrometer. We owe thanks to Fabrice Minoletti (Paris University) for his help in sampling the core, preparing the samples, and for commenting on a previous version of the manuscript. This paper benefited from insightful comments from Pawel Brański, an anonymous reviewer and from Editor Finn Surlyk. We are grateful to the Bureau des Recherches Géologiques et Minières for granting access to the core repository at Orléans. MH was funded by NERC (Postdoctoral fellowship with reference NE/H015523/1).

\section{References}

Arthur, M.A., Dean, W.E., Schlanger, S.O., 1985. Variations in the global carbon cycle during the Cretaceous related to climate, volcanism and changes in atmospheric $\mathrm{CO}_{2}$, in: Sundquist, E.T., Broecker, W.S. (Eds.), The Carbon Cycle and Atmospheric $\mathrm{CO}_{2}$ : Natural Variations Archean to Present. Geophysical Monograph, 32, American Geophysical Union, Washington, 504-529.

Bailey, T.R., Rosenthal, Y., McArthur, J.M., van de Schootbrugge, B., 2003. Paleoceanographic changes of the Late Pliensbachian - Early Toarcian interval: a possible link to the genesis of an Oceanic Anoxic Event. Earth and Planetary Science Letters, 212, 307-320.

Baudin, F., Herbin, J.P., Bassoullet, J.P., Dercourt, J., Lachkar, G., Manivit, H., Renard, M., 1990. Distribution of Organic Matter during the Toarcian in the Mediterranean Tethys and Middle East. AAPG Special Volumes, 6, 73-91.

Bassoulet, J.P., Elmi, S., Poisson, A., Cecca, F., Bellion, Y., Guiraud, R., Baudin, F., 1993. Middle Toarcian (184-182 Ma), in: Dercourt, J., Ricou, L. E., Vrielynck, B. (eds). Atlas Tethys paleoenvironmental maps. Gauthier-Villards, Paris.

Bentablo, M., Ruiz Cruz, M.D., Huertas, F.J., Linares, J., 2003. Hydrothermal transformation of kaolinite to illite at 200 and $300{ }^{\circ} \mathrm{C}$. Clay Mineralogy, 38, 161-172.

Bjerrum, C. J., Surlyk, F., Callomon, J. H., Slingerland, R.L., 2001. Numerical Paleoceanographic Study of the Early Jurassic Transcontinental Laurasian Seaway. Paleoceanography, 16, 390-404.

Blaise, T., Barbarand, J., Kars, M., Ploquin, F., Aubourg, C., Brigaud, B., Cathelineau, M., El Albani, A., Gautheron, C., Izart, A., Janots, D., Michels, R., Pagel, M., Pozzi, J.-P., Boiron, M.-C., Landrein, P., 2014. Reconstruction of low burial $\left(<100{ }^{\circ} \mathrm{C}\right)$ in sedimentary basins: A comparison of geothermometer sensitivity in the intracontinental Paris Basin. Marine and Petroleum Geology, in press, doi.org/10.1016/j.marpetgeo.2013.08.019. 
Boulila, S., Galbrun, B., Huret, E., Hinnov, L. A., Rouget, I., Gardin, S., Bartolini, A., 2014. Astronomical calibration of the Toarcian Stage: Implications for sequence stratigraphy and duration of the early Toarcian OAE. Earth and Planetary Science Letters, 386, 98111.

Brański, P., 2010. Kaolinite peaks in Early Toarcian profiles from the Polish Basin - an inferred record of global warming. Geological Quarterly, 54, 15-24.

Brański, P., 2012. The mineralogical record of the Early Toarcian stepwise climate changes and other environmental variations (Ciechocinek Formation, Polish Basin ). Volumina Jurassica, 10, 1-24.

Chamley, H., 1989. Clay Sedimentology. Springer-Verlag, Heilderberg. 623pp.

Chandler, M. A., Rind, D., Ruedy, R., 1992. Paleoclimate during the early jurassic: GCM simulations and the sedimentary record of paleoclimate. Geological Society of America Bulletin, 104, 543-59.

Cohen, A.S., Coe, A.L., Harding, S.M., 2004. Osmium isotope evidence for the regulation of atmospheric $\mathrm{CO} 2$ by continental weathering. Geology 32, 157-160.

de Graciansky, P.-C., Jacquin, T., Hesselbo, S.P., 1998. The Ligurian cycle: an overview of Lower Jurassic 2nd-order transgressive/regressive facies cycles in western Europe, in: de Graciansky, P.-C., Hardenbol, J., Jacquin, T., Vail, P.R. (Eds.), Mesozoic and Cenozoic Sequence Stratigraphy of European Basins. SEPM (Society for Sedimentary Geology) Special Publication 60, 467-479.

Debrabant, P., Chamley, H., Deconinck, J.-F., Récourt, P., Trouiller, A., 1992. Clay sedimentology, mineralogy and chemistry of Mesozoic sediments drilled in the Northern Paris Basin. Scientific Drilling 3, 138-152.

Deconinck, J.-F, Bernoulli, D, 1991. Clay mineral assemblages of Mesozoic pelagic and flysch sediments of the Lombardian Basin (Southern Alps): Implications for palaeotectonics, palaeoclimate and diagenesis. Geologishe Rundshau, 80, 1-17.

Deconinck, J.-F., Hesselbo, S.P., Debuisser, N., Averbuch, O., 2003. Environmental controls on clay mineralogy of an Early Jurassic mudrock (Blue Lias Formation, southern England). International Journal of Earth Sciences, 92, 255-266.

Deines, P., 2002. The carbon isotope geochemistry of mantle xenoliths. Earth-Science Reviews, 58, 247-278.

Delavenna, M.-F., Steinberg, M., Trauth, N., Holtzapffel, T., 1989. Influence des cycles eustatiques et de la tectonique synsédimentaire sur la minéralogie du Lias et du Dogger $\mathrm{du}$ forage de Sancerre-Couy (Cher). Programme Géologie profonde de la France. Compte-rendus Académie des Sciences, 308, 111-116

Dera, G., Pucéat, E., Pellenard, P., Neige, P., Delsate, D., Joachimski, M. M., Reisberg, L., Martinez, M., 2009a. Water mass exchange and variations in seawater temperature in the NW Tethys during the Early Jurassic: Evidence from neodymium and oxygen isotopes of fish teeth and belemnites. Earth and Planetary Science Letters, 286, 198-207.

Dera, G., Pellenard, P., Neige, P., Deconinck, J.-F., Pucéat, E., Dommergues, J.-L., 2009b. Distribution of clay minerals in Early Jurassic Peritethyan seas: Palaeoclimatic significance inferred from multiproxy comparisons. Palaeogeography, Palaeoclimatology, Palaeoecology, 271, 39-51. 
Dera, G., Brigaud, B., Monna, F., Laffont, R., Puceat, E., Deconinck, J.-F., Pellenard, P., Joachimski, M.M., Durlet, C., 2011. Climatic ups and downs in a disturbed Jurassic world. Geology, 39, 215-218.

Dera, G., Donnadieu, Y., 2012. Modelling evidences for global warming, Arctic seawater freshening, and sluggish oceanic circulation during the Early Toarcian anoxic event. Paleoceanography, 27, PA2211.

Disnar, J.R., Le Strat, P., Farjanel, G., Fikri, A., 1996. Sédimentation de la matière organique dans le nord-est du Bassin de Paris: conséquences sur le dépôt des argilites carbonées du Toarcien inférieur. Chemical Geology, 131, 15-35.

Duncan, R.A., Hooper, P.R., Rehacek, J., Marsh, J.S., Duncan, A.R., 1997. The timing and duration of the Karoo igneous event, southern Gondwana. Journal of Geophysical Research, 102, 18127.

Freeman, K.H., Hayes, J.M., 1992. Fractionation of carbon isotopes by phytoplankton and estimates of ancient $\mathrm{CO}_{2}$ levels. Global Biogeochemical Cycles, 6, 185-198.

Gibbs, R. J., 1977. Clay mineral segregation in the marine environment. Journal of Sedimentary Petrology, 47, 237-243

Gill, B.C., Lyons, T.W., Jenkyns, H.C., 2011. A global perturbation to the sulfur cycle during the Toarcian Oceanic Anoxic Event. Earth and Planetary Science Letters, 312, 484-496.

Godet, A., Bodin, S., Adatte, T., Föllmi, K. B., 2008. Platform-induced clay-mineral fractionation along a northern Tethyan basin-platform transect: implications for the interpretation of Early Cretaceous climate change (Late Hauterivian-Early Aptian). Cretaceous Research, 29, 830-847.

Gómez, J.J., Arias, C., 2010. Rapid warming and ostracods mass extinction at the Lower Toarcian (Jurassic) of central Spain. Marine Micropaleontology, 74, 119-135.

Gómez, J.J., Goy, A., 2011. Warming-driven mass extinction in the Early Toarcian (Early Jurassic) of northern and central Spain. Correlation with other time-equivalent European sections. Palaeogeography, Palaeoclimatology, Palaeoecology, 306, 176-195.

Guillocheau, F. Robin; C., Allemand, P., Bourquin, S., Braulta, N., Dromart, G., Friedenberg, R., Garciboura, J. P., Gaulier, J. M., Gaumet, F., Grosdo, B., Franck Hanot, F., Le Strat, P., Mettraux, M., Nalpas, T., Prijac, C., Rigollet, C., Serrano, O., Grandjean, G., 2000. Meso-Cenozoic geodynamic evolution of the Paris Basin: 3D stratigraphic constraints. Geodinamica Acta, 13, 189-245.

Hallam, A., 2001. A review of the broad pattern of Jurassic sea-level changes and their possible causes in the light of current knowledge. Palaeogeogr. Palaeoclimatol. Palaeoecol. 167, 23-37.

Hanzo, M. Espitalié, J., 1994. Relationship Between Organic Matter and Sedimentation in the Lias of Lorraine (France). Special Publication of the European Association of Petroleum Geoscientists, 4, 121-136.

Hermoso, M., Le Callonnec, L., Minoletti, F., Renard, M., Hesselbo, S.P., 2009a. Expression of the Early Toarcian negative carbon-isotope excursion in separated carbonate microfractions (Jurassic, Paris Basin). Earth and Planetary Science Letters, 277, 194-203.

Hermoso, M., Minoletti, F., Le Callonnec, L., Jenkyns, H.C., Hesselbo, S.P., Rickaby, R.E.M., Renard, M., de Rafélis, M., Emmanuel, L., 2009b. Global and local forcing of Early 
Toarcian seawater chemistry: A comparative study of different paleoceanographic settings (Paris and Lusitanian basins). Paleoceanography, 24, 1-15.

Hermoso, M., Minoletti, F., Rickaby, R.E.M., Hesselbo, S.P., Baudin, F., Jenkyns, H.C., 2012. Dynamics of a stepped carbon-isotope excursion: Ultra high-resolution study of Early Toarcian environmental change. Earth and Planetary Science Letters, 319, 45-54.

Hermoso, M., Minoletti, F., Pellenard, P., 2013. Black shale deposition during Toarcian super-greenhouse driven by sea level. Climate of the Past, 9, 2703-2712.

Hesselbo, S., Grocke, D., Jenkyns, H., Bjerrum, C., Farrimond, P., Morgans Bell HS, Green, O., 2000. Massive dissociation of gas hydrate during a Jurassic oceanic anoxic event. Nature, 406, 392-395.

Hesselbo, S. P., Jenkyns, H. C., Duarte, L.V., Oliveira L. C. V., 2007. Carbon-isotope record of the Early Jurassic (Toarcian) Oceanic Anoxic Event from fossil wood and marine carbonate (Lusitanian Basin, Portugal). Earth and Planetary Science Letters, 253, 455470.

Hesselbo, S.P., Deconinck, J.-F., Huggett, J.M., Morgans-Bell, H.S., 2009. Late Jurassic palaeoclimatic change from clay mineralogy and gamma-ray spectrometry of the Kimmeridge Clay, Dorset, UK. Journal of the Geological Society, 166, 1123-1133.

Hesselbo, S.P., Pieńkowski, G., 2011. Stepwise atmospheric carbon-isotope excursion during the Toarcian Oceanic Anoxic Event (Early Jurassic, Polish Basin). Earth and Planetary Science Letters, 301, 365-372.

Hollander, D.J., Bessereau, G., Belin, S., Huc, A.Y., Houzay, J.P., 1991. Organic matter in the early Toarcian shales, Paris Basin, France: a response to environmental changes. Rev. Inst. Fr. Pétr. 46, 543-562.

Jenkyns, H.C., Gröcke, D.R., Hesselbo, S.P., 2001. Nitrogen isotope evidence for water mass denitrification during the early Toarcian (Jurassic) oceanic anoxic event. Paleoceanography, 16, 593-603.

Jenkyns, H., 2003. Evidence for rapid climate change in the Mesozoic-Palaeogene greenhouse world. Philosophical Transactions of the Royal Society, 361, 1885-1916.

Jenkyns, H.C., 2010. Geochemistry of oceanic anoxic events. Geochemistry Geophysics Geosystems, 11, 1-30.

Jones, C.E., Jenkyns, H.C., 2001. Seawater strontium isotopes, oceanic anoxic events, and seafloor hydrothermal activity in the Jurassic and Cretaceous. American Journal of Science, 301, 112-149.

Jourdan, F., Féraud, G., Bertrand, H., Watkeys, M., Renne, P.R., 2007. Distinct brief major events in the Karoo large igneous province clarified by new 40Ar/39Ar ages on the Lesotho basalts. Lithos, 98, 195-209.

Jourdan, F., Féraud, G., Bertrand, H., Watkeys, M.K., Renne, P.R., 2008. The 40 Ar/ 39 Ar ages of the sill complex of the Karoo large igneous province: Implications for the Pliensbachian-Toarcian climate change. Geochemistry Geophysics Geosystems, 9, Q06009.

Kemp, D. B., Coe, A. L., Cohen, A. S., Schwark, L. 2005. Astronomical pacing of methane release in the Early Jurassic period. Nature, 437, 396-399. 
Lanson, B., Beaufort, D., Berger, G., Bauer, A., Cassagnabere, A., Meunier, A., 2002. Authigenic kaolin and illitic minerals during burial diagenesis of sandstones: a review. Clay Minerals, 37, 1-22.

Lanson, B., Sakharov, B. A., Claret, F., Drits, V. A., 2009. Diagenetic smectite-to-illite transition in clay-rich sediments: A reappraisal of X-ray diffraction results using the multi-specimen method. American Journal of Science, 309, 476-516.

Léonide, P., Floquet, M., Durlet, C., Baudin, F., Pittet, B., Lécuyer, C., 2012. Drowning of a carbonate platform as a precursor stage of the Early Toarcian global anoxic event (Southern Provence sub-Basin, South-east France). Sedimentology, 59, 156-184.

Lézin, C., Andreu, B., Pellenard, P., Bouchez, J.-L., Emmanuel, L., Fauré, P., Landrein, P., 2013. Geochemical disturbance and paleoenvironmental changes during the Early Toarcian in NW Europe. Chemical Geology, 341, 1-15.

Lorenz, J., Gély, J.-P., 1994. Interprétation séquentielle du Jurassique inférieur et moyen du Sud du Bassin Parisien a partir des corrélations diagraphiques calées sur le forage de Couy (Cher, France). Geobios, 27, 597-604.

Lu, Z., Jenkyns, H.C., Rickaby, R.E.M., 2010. Iodine to calcium ratios in marine carbonate as a paleo-redox proxy during oceanic anoxic events. Geology, 38, 1107-1110.

Mailliot, S., Mattioli, E., Guex, J., Pittet, B., 2006. The Early Toarcian anoxia, a synchronous event in the Western Tethys? An approach by quantitative biochronology (Unitary Associations), applied on calcareous nannofossils. Palaeogeography, Palaeoclimatology, Palaeoecology, 240, 562-586.

Mantovani, M., Escudero, A., Becerro, A.I., 2010. Effect of pressure on kaolinite illitization. Applied Clay Sciences, 50, 342-347.

McArthur, J.M., Donovan, D.T., Thirlwall, M.F., Fouke, B.W., 2000. Strontium isotope profile of the early Toarcian (Jurassic) oceanic anoxic event, the duration of ammonite biozones, and belemnite palaeotemperatures. Earth and Planetary Science Letters, 179, 269-285.

McArthur, J.M., Algeo, T.J., van de Schootbrugge, B., Li, Q., Howarth, R.J., 2008. Basinal restriction, black shales, Re-Os dating, and the Early Toarcian (Jurassic) oceanic anoxic event. Paleoceanography, 23, PA4217.

McElwain, J.C., Wade-Murphy, J., Hesselbo, S.P., 2005. Changes in carbon dioxide during an oceanic anoxic event linked to intrusion into Gondwana coals. Nature, 435, 479-482.

Ménétrier, C., Élie, M., Martinez, L., Le, A., 2005. Estimation de la température maximale d'enfouissement du Toarcien et du Callovo-Oxfordien au centre du bassin de Paris par les marqueurs organiques. Comptes Rendus Géoscience, 337, 1323-1330.

Moiroud, M., Martinez, M., Deconinck, J. F., Monna, F., Pellenard, P., Riquier, L., 2012. High-resolution clay mineralogy as a proxy for orbital tuning: Example of the Hauterivian-Barremian transition in the Betic Cordillera (SE Spain). Sedimentary Geology, 282, 336-346.

Moore, D.M., Reynolds, R.C., 1997. X-Ray Diffraction and the Identification and Analysis of 679 Clay Minerals. Oxford University Press, New York, 400 p.

Moulin, M., Fluteau, F., Courtillot, V., Marsh, J., Delpech, G., Quidelleur, X., Gérard, M., Jay, A.E., 2011. An attempt to constrain the age, duration, and eruptive history of the Karoo 
flood basalt: Naude's Nek section (South Africa). Journal of Geophysical Research, 116, $1-27$.

Newton, R.J., Reeves, E.P., Kafousia, N., Wignall, P.B., Bottrell, S.H., Sha, J.-G., 2010. Low marine sulfate concentrations and the isolation of the European epicontinental sea during the Early Jurassic. Geology, 39, 7-10.

Pálfy, J., Smith, P.L., 2000. Synchrony between Early Jurassic extinction, oceanic anoxic event, and the Karoo-Ferrar flood basalt volcanism. Geology, 28, 747-750.

Pearce, C.R., Cohen, A.S., Coe, A.L., Burton, K.W., 2008. Molybdenum isotope evidence for global ocean anoxia coupled with perturbations to the carbon cycle during the Early Jurassic. Geology, 36, 231-234.

Pellenard, P., Deconinck, J.-F., 2006. Mineralogical variability of Callovo-Oxfordian clays from the Paris Basin and the Subalpine Basin. Comptes Rendus Geoscience, 338, 854866.

Petschick, R., 2000. MacDiff 4.2.2. Available online: http://servermac.geologie.unfrankfurt.de/Rainer.html.

Prueher, L. M., and Rea, D. K., 2001. Volcanic triggering of late Pliocene glaciation: Evidence from the flux of volcanic glass and ice-rafted debris to the North Pacific Ocean. Palaeogeography, Palaeoclimatology, Palaeoecology, 173, 215-230.

Raucsik, B., Varga, A., 2008. Climato-environmental controls on clay mineralogy of the Hettangian-Bajocian successions of the Mecsek Mountains, Hungary: An evidence for extreme continental weathering during the early Toarcian oceanic anoxic event. Palaeogeography, Palaeoclimatology, Palaeoecology, 265, 1-13.

Raup, D.M., Sepkoski, J.J., 1984. Periodicity of extinctions in the geologic past. Proceedings of the National Academy of Sciences of the United States of America, 81, 801-805.

Robock, A., 2000. Volcanic eruptions and climate. Reviews of Geophysics, 38, 191-219.

Röhl, H.-J., Schmid-Röhl, A., Oschmann, W., Frimmel, A., Schwark, L., 2001. The Posidonia Shale (Lower Toarcian) of SW-Germany: an oxygen-depleted ecosystem controlled by sea level and palaeoclimate. Palaeogeography, Palaeoclimatology, Palaeoecology, 165, $27-52$.

Rosales, I., Quesada, S., and Robles, S., 2004. Paleotemperature variations of Early Jurassic seawater recorded in geochemical trends of belemnites from the Basque-Cantabrian basin, northern Spain. Palaeogeography, Palaeoclimatology, Palaeoecology, 203, 253-275.

Sælen, G., Doyle, P., and Talbot, M. R., 1996. Stable-Isotope Analyses of Belemnite Rostra from the Whitby Mudstone Fm., England: Surface Water Conditions During Deposition of a Marine Black Shale. Palaios, 11, 97-117.

Suan, G., Pittet, B., Bour, I., Mattioli, E., Duarte, L., Mailliot, S., 2008. Duration of the Early Toarcian carbon isotope excursion deduced from spectral analysis: Consequence for its possible causes. Earth and Planetary Science Letters, 267, 666-679.

Suan, G., Mattioli, E., Pittet, B., Lécuyer, C., Suchéras-Marx, B., Vítor, L., Philippe, M., Reggiani, L., Martineau, F., Duarte, L.V., 2010. Secular environmental precursors to Early Toarcian (Jurassic) extreme climate changes. Earth and Planetary Science Letters, 290, 448-458.

Suan, G., Rulleau, L., Mattioli, E., Suchéras-Marx, B., Rousselle, B., Pittet, B., Vincent, P., Martin, J.E., Léna, A., Spangenberg, J.E., Föllmi, K.B., 2013. Palaeoenvironmental 
significance of Toarcian black shales and event deposits from southern Beaujolais, France. Geological Magazine, 150, 728-742.

Thiry, M., 2000. Palaeoclimatic interpretation of clay minerals in marine deposits: an outlook from the continental origin. Earth-Science Reviews, 49, 201-221.

Trecalli, A., Spangenberg, J., Adatte, T., Föllmi, K.B., Parente, M., 2012. Carbonate platform evidence of ocean acidification at the onset of the early Toarcian oceanic anoxic event. Earth and Planetary Science Letters, 357, 214-225.

Van Breugel, Y. Van, Baas, M., Schouten, S., Mattioli, E., Damste, J.S.S., 2006. Isorenieratane record in black shales from the Paris Basin, France: Constraints on recycling of respired $\mathrm{CO}_{2}$ as a mechanism for negative carbon isotope shifts during the Toarcian oceanic anoxic event, Paleoceanography, 21, 1-8.

Van de Schootbrugge, B., McArthur, J.M., Bailey, T.R., Rosenthal, Y., Wright, J.D., Miller, K.G. 2005. Toarcian oceanic anoxic event: An assessment of global causes using belemnite C isotope records. Paleoceanography, 20, PA3008.

Voigt, S., Gale, A.S., Flögel, S., 2004. Midlatitude shelf seas in the Cenomanian-Turonian greenhouse world: Temperature evolution and North Atlantic circulation. Paleoceanography, 19, PA4020. 